\title{
KURIKULUM BAHASA INDONESIA: PROBLEMATIKA DI LAPANGAN
}

\author{
oleh Bambang Yulianto \\ FBS Universitas Negeri Surabaya
}

\begin{abstract}
Those putting KBK/KTSP (short for Kurikulum Berdasar Kompetensi/ Kurikulum Tingkat Satuan Pendidikan or the Competency-Based Curriculum/the Curriculum at the Level of Educational Unit) of Bahasa Indonesia into practice still encounter an abundance of problems in the field. The problems involve its implementation in relation to the teachers, the students, and the supporting facilities. The implementation has indicated (a) the teachers' lack of understanding of the curriculum of Bahasa Indonesia in both the addition of basic competencies and the concepts of learning concerning linguistic aspects; (b) the teachers' apathetic attitude towards the curriculum because of their desire for uniformity and the increasingly heavier load of their duties; and (c) the teachers' lack of knowledge of efforts for maximum development of the curriculum such as practicing authentic assessment, selecting suitable lesson books, and running remedial and enrichment programs. As an impact of the implementation on the students, a sufficiently large number of students feel burdened with KBK because they already have many assignments in both their regular and remedial classes. As an impact of the implementation on the support facilities, it has brought to light that regional schools lack the facilities that could meet the demands of the curriculum.
\end{abstract}

Keywords: KBK/KTSP, teachers' attitude, impacts, problems

\section{A. PENDAHULUAN}

Salah satu implikasi diberlakukannya otonomi daerah adalah otonomi pendidikan. Di samping karena adanya fakta hasil pendidikan yang tidak merata di setiap daerah, seringkali kebutuhan dan permasalahan pendidikan daerah yang berbeda-beda selalu diatasi dengan cara yang sama, seragam. Apalagi, kebijakan pusat seringkali tidak sesuai dengan kondisi di lapangan selain juga datangnya sering terlalu terlambat sampai di tingkat bawah (daerah). Dalam hal yang demikian potensi akademis yang ada di daerah tidak bisa dimanfaatkan secara maksimal (Suryadi, 2001). Akibatnya, kondisi tersebut tidak mampu memacu persaingan yang sehat untuk meningkatkan kualitas pendidikan, kecuali untuk memenuhi target kebijakan. Kenyataan inilah yang ikut mendorong pemikiran diperlukannya otonomi pendidikan.

Dalam otonomi pendidikan terbuka peluang untuk menciptakan pendidikan di daerah menjadi lebih berkualitas karena pejabat daerah memiliki wewenang yang luas untuk melakukan antisipasi dalam rangka meningkatkan kualitas pendidikan di daerahnya (Mudjiharto, 2000; Suyanto, 2001). Kegiatan rekrutmen untuk kepala sekolah, guru, dan siswa; pembinaan profesionalisme guru; penentuan sistem evaluasi; dan sebagainya ditentukan oleh daerah (pemerintah provinsi, sekolah, dan masyarakat) (lihat Stinnett, 1968; Dorros, 1978). Dengan demikian, kualitas hasilnya sangat ditentukan oleh kemampuan dan kemauan daerah (Kompas, 2001). 
Peningkatan mutu pendidikan dapat dilakukan melalui penciptaan iklim pembelajaran yang kondusif bagi terlaksananya kurikulum yang fleksibel, yakni yang sesuai dengan potensi sekolah. Semangat yang demikian ini ditangkap oleh pemerintah melalui penciptaan Kurikulum Berbasis Kompetensi (KBK), yang kemudian berubah menjadi Kurikulum Tingkat Satuan Pendidikan (KTSP). Baik KBK maupun KTSP (kedua nama kurikulum tersebut pada tulisan ini digunakan bersama-sama karena secara substansial dalam pendekatannya keduanya tidak berbeda) memberikan keleluasaan kepada sekolah untuk menyusun dan mengembangkan silabus mata pelajaran yang sesuai dengan kebutuhan masyarakat, kebutuhan dan kemampuan siswa, serta potensi sekolah. Dengan demikian, dimungkinkan terjadi variasi silabus mata pelajaran untuk setiap sekolah. Meskipun demikian, penyusunannya tidak mengurangi kompetensi dasar yang telah ditetapkan berlaku secara nasional.

Penerapan KBK/KTSP di sekolah harus dihubungkan dengan kebijakan pemerintah dalam pelaksanaan Pendidikan Berbasis Masyarakat Luas (Broad Based Education, BBE) dalam kerangka program peningkatan mutu pendidikan. Dalam hal ini penerapan kurikulum menggunakan konsep BBE yang berorientasi pada kecakapan hidup (Life Skill) dengan mendayagunakan semua potensi sumber belajar yang dimiliki sekolah dan yang ada di sekitar sekolah (Depdiknas, 2002b). Untuk itu, diperlukan restrukturisasi pembelajaran di sekolah dengan cara mengidentifikasi aspek-aspek kecakapan hidup yang akan diajarkan dalam setiap tema, hasil belajar, atau mata pelajaran. Pengidentifikasian ini diperlukan untuk melihat persebaran dan pemerataan serta penekanan yang diperlukan untuk setiap jenjang pendidikan.

Di samping itu, arus informasi global tentang dunia pendidikan ikut mewarnai arah pendidikan di tanah air. Sejak publikasi Ivan Illich 'Deschooling Society' (1970), terpicu dialog dalam menuntut peningkatan kualitas pendidikan, terutama di Amerika Serikat.
Menurut Illich (1970), sekolah yang dikelola pemerintah memperlakukan pengetahuan sebagai suatu komoditas, mematikan keinginan anak untuk belajar, dan hanya memantapkan struktur yang artifisial untuk 'keberhasilan' yang secara sosial sangat membahayakan sebab mereka tidak mampu memanfaatkan sistem itu.

Untuk itu, diperlukan pembentukan 'jaringan pembelajaran' (learning network), yang akan memberikan keramahan (convivial acces) pada peralatan, teknik, dan pelayanan. Ia menghendaki adanya suatu komunitas tempat orang-orang dari semua tingkatan umur berkumpul bersama untuk bertukar keterampilan dan ide-ide, yang dikembangkan secara luas. Dengan atmosfir yang demikian, proses belajar akan lebih nyata, tidak dibuat-buat, dan orang akan dievaluasi berdasarkan apa yang diketahui dan dikerjakan tanpa harus menggunakan waktu bertahun-tahun dalam menyelesaikan suatu program sekolah.

Dalam hal ini belajar adalah cara untuk memperoleh keterampilan dan pandanganpandangan baru, sedangkan upaya perluasannya bergantung pada apa yang telah diketahui oleh siswa. Belajar sering dianggap merupakan hasil suatu pengajaran. Padahal, banyak pengetahuan yang diperoleh seseorang di luar sekolah. Anak-anak dapat menguasai bahasa pertamanya bukan karena pengajaran yang terprogram. Banyak orang belajar bahasa kedua dengan baik juga bukan karena sistem pengajaran. Kelancaran membaca juga lebih sering diperoleh bukan di sekolah.

Pengajaran sudah menjadi alat untuk mendorong siswa berdasarkan kurikulum yang telah dirancang sebelumnya dan siswa diharuskan memenuhinya dalam memperoleh nilai berupa angka-angka. Sekolah menghubungkan pengajaran dan bukan belajar untuk melakukan peranan. Menurutnya, sekolah tidak memberikan kebebasan, tidak menjamin hubungan kualitas dengan kompetensi yang relevan, tidak mendidik, tidak memberikan kemerdekaan, dan kurikulumnya hanya menciptakan tingkatan sosial. Kritik terhadap kelemahan sistem persekolahan tersebut demikian tajam, sehingga lebih memberikan 
kesan memojokkan sekolah dibandingkan dengan keinginan memperbaikinya (Goodlad, 1984).

Problem baru dalam dunia pendidikan kemudian bertambah lagi seiring dengan adanya pertumbuhan ekonomi yang tinggi, perluasan kesempatan kerja, serta perkembangan teknologi media massa dan pertelevisian. Isu yang muncul adalah sebagai berikut: (1) sekolah diharapkan mengatasi keadaan tersebut karena semakin banyak orang tua yang sibuk bekerja; (2) hubungan yang lemah antara sekolah dan keluarga menyebabkan sekolah terbebani; (3) perubahan ekonomi mempengaruhi perilaku masyarakat; (4) guru lebih mengarah menjadi anggota organisasi profesi sesuai bidang studinya daripada memperhatikan seluruh proses pendidikan; (5) guru tidak dipersiapkan untuk menghadapi berbagai macam kondisi dan latar belakang siswa; dan (6) anak dapat memperoleh pendidikan dari sumber-sumber lain selain sekolah.

Berdasarkan hal itu, tampak bahwa terdapat pergeseran dalam paradigma pendidikan, yakni dari pembelajaran kelompok (klasikal) ke arah pembelajaran individual. Dalam pembelajaran individual setiap siswa dapat belajar sendiri sesuai dengan cara dan kemampuan msing-masing, serta tidak bergantung kepada orang lain (kelompoknya). Untuk itu, diperlukan pengaturan kelas yang fleksibel, sarana yang mencukupi dan beragam, serta pengaturan waktu yang memadai karena dimungkinkan siswa mempelajari konsep yang berbeda dengan sarana dan kecepatan yang berbeda-beda.

\section{B. KONSEP PELAKSANAAN KBK/KTSP}

Pelaksanaan kurikulum kita menerapkan prinsip Kesatuan dalam Kebijakan dan Keberagaman dalam Pelaksanaan. Standar nasional disusun pusat dan cara pelaksanaannya disesuaikan masing-masing daerah/sekolah dan madrasah. Perwujudan Kesatuan dalam Kebijakan tertuang dalam pengembangan Kerangka Dasar, Standar Kompetensi Bahan Kajian, dan Standar Kompetensi Mata Pelajaran, beserta Pedoman Pelaksanaannya.
Perwujudan Keberagaman dalam Pelaksanaan tertuang dalam pengembangan silabus dan skenario pembelajaran.

Pelaksanaan kurikulum di daerah mempertimbangkan hal-hal berikut:

(1) perencanaan dan pelaksanaan pendidikan sesuai dengan standar yang ditetapkan;

(2) perluasan kesempatan berimprovisasi dan berkreasi dalam meningkatkan mutu pendidikan;

(3) penegasan tanggung jawab bersama antara orang tua, sekolah dan madrasah, masyarakat, pemerintah daerah, dan pemerintah pusat dalam meningkatkan mutu pendidikan;

(4) peningkatan pertanggungjawaban (akuntabilitas) kinerja penyelenggaraan pendidikan;

(5) perwujudan keterbukaan dan kepercayaan dalam pengelolaan pendidikan sesuai dengan otoritas masing-masing yang dapat membangun kesatuan dan persatuan bangsa;

(6) penyelesaian masalah pendidikan sesuai dengan karakteristik wilayah yang bersangkutan.

Kurikulum dapat didiversifikasikan dengan cara disesuaikan, diperluas, dan diperdalam untuk melayani keberagaman penyelenggaraan satuan pendidikan, kebutuhan dan kemampuan daerah dan sekolah dan madrasah ditinjau dari segi geografis dan budaya serta kemampuan dan minat peserta didik sehingga sekolah dan madrasah dapat melayani seluruh peserta didik dengan kemampuan di bawah rata-rata, rata-rata, dan di atas rata-rata untuk mencapai hasil yang optimal.

Diversifikasi kurikulum yang melayani minat peserta didik dan kebutuhan daerah dirancang oleh daerah dan sekolah dan madrasah. Perwujudan diversifikasi kurikulum pendidikan kejuruan mengacu pada pencapaian penguasaan kompetensi sesuai dengan dunia kerja setempat.

Diversifikasi kurikulum juga dilaksanakan untuk melayani peserta didik 
yang memiliki tingkat kesulitan dalam mengikuti proses pembelajaran karena kelainan fisik, emosional, mental, sosial dan/atau memiliki potensi kecerdasan dan bakat istimewa. Diversifikasi kurikulum juga perlu dilaksanakan untuk peserta didik dari daerah terpencil atau terbelakang, masyarakat adat yang terpencil, dan/atau mengalami bencana alam, bencana sosial, dan tidak mampu dari segi ekonomi.

Kurikulum 2004 ini dilaksanakan mulai tahun pelajaran 2004/2005 dan KTSP dilaksanakan mulai tahun pelajaran 2006/2007 secara bertahap bagi sekolah dan madrasah yang telah siap melaksanakannya dengan penahapan sebagai berikut.

(1) Pada tahun pertama kurikulum diterapkan pada Kelas I dan Kelas IV SD/MI, Kelas VII SMP/MTs, serta Kelas X SMA/SMK dan MA/MAK.

(2) Pada tahun kedua kurikulum dilaksanakan di Kelas I, II, IV, V SD/MI, Kelas VII, VIII SMP/MTs, serta Kelas X, XI SMA/SMK dan MA/MAK.

(3) Pada tahun ketiga dan seterusnya dilaksanakan pada seluruh kelas di SD/MI, SMP/MTs, serta SMA/SMK dan MA/MAK.

Sekolah/madrasah yang belum siap melaksanakan kurikulum mulai tahun pelajaran tersebut diharapkan dapat memulainya paling lambat tiga tahun sejak tahun tersebut dengan penahapan yang sama seperti di atas. Dalam kenyataannya, belum seluruh sekolah menggunakan Kurikulum 2004, terbit KTSP mulai tahun 2006.

\section{IMPLEMENTASI KBK DI LAPANGAN}

Perkembangan sikap para guru akhirakhir ini cukup membanggakan. Semangat mereka untuk memahami dan sekaligus melaksanakan amanat KBK/KTSP tampak cukup tinggi. Sejak sekitar akhir tahun 2001 (konsep KBK mulai diperkenalkan di masyarakat) hingga sekarang, kegiatan seminar yang bertopik KTSP selalu dihadiri oleh guru dengan antusias. Yayasan yang mengelola sekolah swasta, kelompok guru bidang studi, Dinas Pendidikan di kota atau kabupaten berusaha menghadirkan narasumber dari perguruan tinggi untuk kegiatan-kegiatan tersebut. Jika dihitung jumlah kegiatan tersubut cukup banyak setiap tahunnya. Kenyataan yang demikian tidak dapat kita amati pada waktu sosialisasi Kurikulum 1994. Hal itu menunjukkan bahwa pada umumnya masyarakat, khususnya para guru, menaruh perhatian dan harapan yang besar pada KBK/KTSP ini.

Oleh karena itu, bisa dipastikan bahwa hampir semua guru hingga saat ini telah mengenal KBK (Kurikulum 2004) ataupun KTSP, baik guru yang saat ini mengajar dengan menggunakan KTSP maupun guru yang saat ini masih menggunakan Kurikulum 2004 atau bahkan Kurikulum 1994. Namun, apakah semua guru yang telah menggunakan Kurikulum 2004 atau KTSP telah memahaminya dengan baik? Apakah mereka telah melaksanakan amanat kurikulum tersebut dengan baik pula?

Dari beberapa kegiatan seminar, lokakarya, atau pelatihan yang diikuti penulis sebagai narasumber, tercatat beberapa hal yang dapat dijadikan bahan renungan berkaitan dengan implementasi KBK/KTSP di lapangan (data ini bukan data penelitian), yang dapat dikaitkan dengan guru, siswa, metode pembelajaran, evaluasi, media (sarana dan prasarana), dan isi kurikulum itu sendiri. Sementara itu, untuk menilai apakah suatu kurikulum itu baik atau tidak, dapat diperhatikan petunjuk yang diberikan oleh Nunan (1988:121-122), yang membagi tiga aspek penilaian, yaitu proses perencanaan, implementasi, dan evaluasi (bandingkan pula dengan Richards, 2001:40, yang membaginya dalam empat tahapan: analisis kebutuhan, perencanaan, implementasi, dan evaluasi). 


\begin{tabular}{|c|c|c|}
\hline & Wilayah kurikulum & Pertanyaan \\
\hline & $\begin{array}{l}\text { Proses perencanaan: } \\
\text { 1. Analisis kebutuhan: }\end{array}$ & $\begin{array}{l}\text { Apakah prosedur analisis kebutuhan berjalan secara efektif? } \\
\text { Apakah analisis kebutuhan menyediakan informasi yang cukup } \\
\text { untuk perencanaan mata pelajaran? } \\
\text { Apakah analisis kebutuhan menyediakan data untuk kebutuhan } \\
\text { secara individual maupun kelompok? } \\
\text { Apakah data yang disediakan dapat diterapkan dalam isi } \\
\text { kurikulum? }\end{array}$ \\
\hline & 2. Isi kurikulum: & $\begin{array}{l}\text { Apakah tujuan diturunkan dari analisis kebutuhan? } \\
\text { Apakah tujuan tersebut cocok untuk kelompok khusus pebelajar? } \\
\text { Apakah pebelajar berpikir bahwa isi kurikulum itu cocok bagi } \\
\text { mereka? } \\
\text { Apakah isi kurikulum itu telah ditata berdasarkan urutan yang } \\
\text { memadai? }\end{array}$ \\
\hline & $\begin{array}{l}\text { Implementasi: } \\
\text { 1. Metodologi }\end{array}$ & $\begin{array}{l}\text { Apakah materi, metode, dan aktivitas belajar telah sesuai dengan } \\
\text { tujuan yang ditetapkan? } \\
\text { Apakah pebelajar berpikir bahwa materi, metode, dan aktivitas } \\
\text { belajar cocok dengan mereka? }\end{array}$ \\
\hline & $\begin{array}{l}\text { 2. Guru atau sumber } \\
\text { belajar }\end{array}$ & $\begin{array}{l}\text { Apakah sumber belajar telah memadai? } \\
\text { Apakah guru memiliki kemampuan mengelola kelas secara } \\
\text { memadai? }\end{array}$ \\
\hline & 3. Pembelajar & $\begin{array}{l}\text { Apakah strategi belajar pebelajar cukup efisien? } \\
\text { Apakah pebelajar datang secara reguler? } \\
\text { Apakah pebelajar menaruh perhatian pada kelas? } \\
\text { Apakah pebelajar menerapkan keterampilan mereka di luar kelas? } \\
\text { Apakah pebelajar tampak senang dalam pelajaran? } \\
\text { Apakah waktu dan tipe-tipe belajar diatur sesuai dengan kebutuhan } \\
\text { siswa? } \\
\text { Apakah masalah-masalah personal pebelajar mempengaruhi } \\
\text { pemelajaran? }\end{array}$ \\
\hline & Evaluasi & $\begin{array}{l}\text { Apakah prosedur penilaian cocok dengan tujuan? } \\
\text { Apakah ada kesempatan bagi pebelajar untuk melakukan penilaian } \\
\text { diri? Jika ada, apa dan bagaimana dilakukan? } \\
\text { Apakah ada kesempatan bagi pebelajar untuk menilai aspek } \\
\text { pelajaran seperti materi, metodologi, dan pengaturan pemelajaran? } \\
\text { Apakah ada kesempatan bagi guru untuk melakukan evaluasi diri? }\end{array}$ \\
\hline
\end{tabular}

Nunan (1988:121-122)

Jawaban terhadap pertanyaanpertanyaan tersebut akan menggambarkan seberapa kualitas kurikulum itu. Kawasan perencaaan telah dilakukan dengan cermat, tentunya, oleh pemerintah. Analisis kebutuhan yang akan menentukan isi kurikulum dan arah kebijakan pendidikan secara umum telah dilakukan oleh para pakar penyusun kurikulum. Mereka setidak-tidaknya telah mencermati kebutuhan para lulusan setiap jenjang sekolah. Mereka juga, tentunya, telah mempertimbangkan kompetensi lulusan dalam pergaulan 
internasional. Kenyataan tentang keterpurukan hasil pendidikan di Indonesia dibandingkan dengan negara lain, terutama dengan negara tetangga pastilah menjadi pemicu.

Berdasarkan berbagai hasil laporan ditengarai bahwa keadaan sumber daya manusia di Indonesia sangat tidak kompetitif. Menurut catatan Human Development Report Tahun 2000 versi UNDP, peringkat HDI (Human Develompment Index) atau kualitas Sumber Daya Manusia Indonesia berada di urutan 105 dari 108 negara. Indonesia berada jauh di bawah Filipina (77), Thailand (76), Malaysia (61), Brunei Darussalam (32), Korea Selatan (30), dan Singapura (24). Organisasi internasional yang lain juga menguatkan hal itu. International Educational Achievement (IEA) melaporkan bahwa kemampuan membaca siswa SD Indonesia berada di urutan 38 dari 39 negara yang disurvai. Sementara itu, Third Matemathics and Science Study (TIMSS), lembaga yang mengukur hasil pendidikan di dunia, melaporkan bahwa kemampuan matematika siswa SMP kita berada di urutan 34 dari 38 negara, sedangkan kemampuan IPA berada di urutan ke-32 dari 38 negara. Jadi, keadaan pendidikan kita memang memprihatinkan (Dit. PLP, 2003). Untuk itu, pembaharuan pendidikan harus terus dilakukan.

Rendahnya mutu sumber daya manusia Indonesia itu tentu tidak lepas dari hasil-hasil yang dicapai oleh pendidikan kita. Ada banyak persoalan yang dihadapi dunia pendidikan kita. Untuk mengejar ketertinggalan itu, perlu diupayakan penataan pendidikan yang bermutu. Untuk mencapai itu, pendidikan harus adaptif terhadap perubahan zaman.

Di samping itu, tuntutan realitas politik dan sosial turut mewarnai arah kebijakan pendidikan. Lahirnya berbagai kebijakan pemerintah, seperti (1) pemberlakuan Undangundang Nomor 22 tahun 1999 tentang Otonomi Daerah, (2) Peraturan Pemerintah Nomor 25 tahun 2000 tentang Kewenangan Pemerintah dan Daerah sebagai Daerah Otonom, yang antara lain menyatakan bahwa Pemerintah Pusat berkewenangan dalam menentukan kompetensi siswa, kurikulum, dan materi pokok; penilaian nasional; dan kalender pendidikan; (3) Garis-garis Besar Haluan Negara tahun 1999 yang antara lain menyatakan perlunya dilakukan penyempurnaan kurikulum pendidikan; (4) Gerakan Peningkatan Mutu Pendidikan yang telah dicanangkan oleh Presiden Republik Indonesia pada peringatan Hari Pendidikan Nasional 2 Mei 2002.

Ketimpangan terjadi pada semua sendi kehidupan, seperti moral, akhlak, jati diri bangsa, sosial dan politik, serta ekonomi. Semakin terbatasnya sumber alam dan kesempatan untuk memperoleh pekerjaan dan kehidupan yang layak pada tingkat lokal, nasional, dan persaingan pada tingkat global menjadi hal yang harus diperhitungkan. Perkembangan ilmu pengetahuan dan teknologi yang semakin pesat memberikan dampak terhadap kehidupan. Faktor-faktor sosial tersebut menjadi acuan dalam area analisis kebutuhan.

Selanjutnya, arahan Nunan (1988) tersebut disesuaikan dengan kenyataan di lapangan dalam implementasinya. Dalam pembicaraan ini implementasi kurikulum melibatkan dan dibatasi pada guru, siswa, dan sarana pendukungnya.

\section{Implementasi Kurikulum bagi Guru}

Ada tiga komponen yang terkait dengan implementasi kurikulum bagi guru, yakni pemahaman guru terhadap kurikulum, sikap guru terhadap kurikulum, dan upaya pengembangan kurikulum yang telah dilakukan guru. Data-data yang disajikan berikut tidak seluruhnya diambil dari penelitian, tetapi diambil dari pengamatan atau catatan penulis selama menjadi narasumber dalam berbagai seminar, lokakarya, dan pelatihan yang melibatkan guru, khususnya guru bahasa Indonesia, baik guru SD/MI, SMP/MTs, maupun SMA/MA. Data lain diambil dari hasil penelitian sementara Kuswandi (2005) yang meneliti implementasi KBK pada tiga SMA di Surabaya: SMAK Petra 2 Surabaya, SMA Muhammadiyah 2 Surabaya, dan SMAN 2 Surabaya. Ketiga SMA tersebut merupakan pilot project uji coba KBK sejak 2002. 


\section{Pemahaman Guru terhadap Kurikulum}

Hampir dalam setiap pelatihan yang melibatkan penulis sebagai narasumber, penulis mencatat bahwa pada umumnya guru tidak menambahkan kompetensi dasar atau butir indikator (hasil belajar) pada waktu mengembangkan silabus. Padahal, dalam dokumen kurikulum ditegaskan bahwa KBK ataupun KTSP hanyalah memuat komponen kompetensi dasar minimal yang harus dikuasai siswa. Karena itu, guru harus mengembangkannya, baik melalui penambahan komponen kompetensi maupun hasil belajar. Guru dituntut mengembangkan sendiri silabus pembelajaran, baik secara individual maupun kelompok. Sekolah yang memiliki kemampuan mandiri dapat menyusun silabus yang sesuai dengan kondisi dan kebutuhannya setelah mendapatkan persetujuan dari Dinas Pendidikan (provinsi atau kabupaten/kota). Penyusunan silabus dapat dilakukan dengan melibatkan para ahli atau instansi yang relevan di daerah setempat, seperti tokoh masyarakat, instansi pemerintah, instansi swasta, termasuk perusahaan dan industri, atau perguruan tinggi.

Sejalan dengan kebijakan pemerintah dalam pencanangan mutu pendidikan dan pelaksanaan otonomi daerah, Pusat berkewenangan dalam menentukan: kompetensi siswa, kurikulum dan materi pokok, penilaian nasional, serta kalender pendidikan. Dengan kata lain pusat menentukan standar kurikulum yang dalam hal ini adalah kerangka kurikulum dan hasil belajar; kerangka penilaian berbasis kelas; kerangka kegiatan pembelajaran; dan kerangka pengelolaan kurikulum berbasis sekolah. Kalender pendidikan yang dijabarkan dalam bentuk alokasi waktu pembelajaran tiap minggu dalam setahun di SD, SLTP dan SMA juga ditetapkan oleh pusat. Dalam KBK/KTSP beban (alokasi waktu tatap muka) siswa per minggu berkurang dibandingkan dengan kurikulum sebelumnya.

Daerah dalam hal ini adalah tingkat II dan sekolah berperan untuk mengembangkan silabus berdasarkan kerangka kurikulum yang ditetapkan pusat. Silabus yang disusun daerah/ sekolah diharapkan lebih sesuai dengan kondisi dan aspirasi mereka. Daerah/sekolah dapat menambah materi pelajaran sesuai dengan kepentingannya dan layak dilaksanakan.

Kenyataan di atas menampakkan bahwa guru masih menggunakan cara kerja lama yang dikenal dengan GBPP (Garis-garis Besar Program Pengajaran). Guru dalam melaksanakan kurikulum tidak pernah menambah atau mengurangi apa yang terdapat dalam GBPP. Hal itu menunjukkan bahwa pemahaman guru tentang Kurikulum 2004 atau KTSP belum baik benar. Meskipun, tanpa mengurangi pemahaman guru secara komprehensif dalam mengisi angket, dalam angket yang diisi guru di tiga sekolah yang disebutkan di atas terjawab bahwa 99\% guru mengaku telah memahami dengan baik KBK.

Ketika dalam berbagai kesempatan penulis bertanya kepada guru apakah aspek kebahasaan (tata bahasa) dalam Kurikulum 2004 atau KTSP diabaikan, kurang ditonjolkan, kurang mendapatkan porsi yang memadai, mereka pada umumnya menjawab ya karena pada Kurikulum 1994 aspek tata bahasa (struktur) tercantum secara eksplisit pada GBPP, sedangkan dalam Kurikulum 2004 dan KTSP hal itu tidak terjadi. Halnya berbeda dengan yang tampak pada beberapa kurikulum sebelumnya. Pada Kurikulum 1975 tampak sekali bahwa tata bahasa memperoleh porsi yang teratas. Pembelajaran bahasa lebih berorientasi pada pembelajaran tentang bahasa. Pada Kurikulum 1984 peranannya tidak terlalu menonjol, namun kehadirannya masih terasa. Pada Kurikulum 1994 posisinya semakin berkurang, namun dalam GBPP kehadirannya masih tampak. Pada Kurikulum 2004 aspek tata bahasa dicantumkan dalam lampiran dan pada KTSP lampiran tentang struktur kebahasaan malahan tidak ada.

Berdasarkan hal itu, tampak bahwa tata bahasa tidak memperoleh tempat yang memadai. Sebaliknya, bidang sastra tampak lebih dominan, bila dibandingkan dengan tata bahasa. Padahal, dalam kurikulum sebelumnya, sastra tidak sebanding dengan tata bahasa. Benarkah anggapan bahwa tata bahasa tidak mendapatkan porsi yang memadai tersebut? 
Untuk menjawab itu, ada baiknya diperhatikan prinsip-prinsip pembelajaran bahasa secara umum, yakni sebagai berikut: (1) pembelajaran bahasa Indonesia harus diarahkan untuk lebih banyak memberikan porsi kepada perlatihan berbahasa yang nyata; (2) tata bahasa diajarkan hanya untuk membetulkan kesalahan ujaran siswa; (3) keterampilan berbahasa nyata menjadi tujuan utama; (4) membaca sebagai alat untuk belajar (reading for learning); (5) menulis dan berbicara sebagai alat berekspresi dan menyampaikan gagasan; (6) kelas menjadi tempat berlatih menulis, membaca, dan berbicara dalam bahasa; (7) penekanan pengajaran sastra pada membaca sebanyakbanyaknya karya sastra, dan (8) pengajaran kosa kata harus diarahkan untuk menambah kosa kata anak. Berdasarkan hal itu, tampak bahwa arah pembelajaran bahasa adalah memperbanyak berlatih di dalam kelas dengan menggunakan bahasa yang sesuai dengan situasi, baik yang nyata 'senyatanya' melalui diskusi, misalnya, maupun yang nyata 'tidak senyatanya', misalnya melalui kegiatan bermain peran.

Sementara itu, prinsip-prinsip pembelajaran tata bahasa adalah sebagai berikut. Pertama, pembelajaran komponen kebahasaan merupakan pelatihan pemahaman dan penggunaan bahasa yang bermakna sesuai dengan keperluan komunikasi. Dalam hal ini kegiatan utama pembelajaran komponen kebahasaan melalui pemberian latihan yang terus-menerus dalam berbagai situasi kebahasaan yang bermakna. Pelatihan itu harus diarahkan untuk mendukung, baik kemampuan aspek pemahaman (menyimak dan membaca), maupun kemampuan penggunaan (berbicara dan menulis). Kedua, pembelajaran komponen kebahasaan terintegrasi ke dalam pembelajaran keterampilan berbahasa. Prinsip ini sebenarnya merupakan implikasi prinsip pertama. Berdasarkan prinsip ini, komponen kebahasaan tidak diajarkan secara mandiri. Contoh-contoh yang disajikan haruslah yang fungsional berdasarkan penggunaannya, baik secara reseptif, maupun produktif. Dengan demikian, pembelajaran komponen kebahasaan terfokus kepada penggunaan bahasa secara fungsional dan bermakna sesuai dengan tujuan dan keperluan komunikasi. Oleh karena itu pula, pembelajaran kebahasaan mengarah kepada kemungkinan variasi-veriasi berbahasa. Ketiga, pembelajaran komponen kebahasaan tidak menganut tahap-tahap pembelajaran secara linguistis. Komponen fonologi tidak harus diajarkan lebih dahulu dibandingkan dengan komponen morfologi ataupun sintaksis. Pembelajaran sintaksis, misalnya, harus berlangsung secara terpadu berdasarkan wacana yang kontekstual, fungsional, bermakna, dan bermanfaat, baik bagi siswa maupun lingkungannya. Dengan demikian, contoh-contoh kalimat yang konkret berdasarkan wacana itulah yang dapat menjadi bahan kajian. Dalam hal ini, pemilihan bahan yang tepat menjadi kunci keberhasilan pembelajarannya.

Berdasarkan prinsip-prinsip di atas tampak bahwa tata bahasa itu dapat diajarkan (disajikan) kapan saja (di awal, tengah, akhir pelajaran) dan dalam kondisi apa saja (fokus pembelajaran membaca, menulis, berbicara, maupun mendengarkan). Kehadirannya tidak perlu direncanakan karena tata bahasa diajarkan bila terdapat kesalahan pada pemakaian bahasa siswa. Karena itu, urutannya juga akan beragam antara kelas yang satu dengan yang lain pada level yang sama. Secara konkret begini. Materi untuk kelas 8 , misalnya, dapat saja disajikan pada kelas 7 saat itu juga jika memang siswa kelas 7 melakukan kesalahan berbahasa yang sesuai dengan materi 8 dalam lampiran (model Kurikulum 2004). Dengan demikian, guru tidak harus menunda membicarakannya setahun lagi setelah anak duduk di kelas 8. Bagitu pula sebaliknya, kompetensi gramatikal tertentu yang tercantum di kelas 7, misalnya, tidak harus disajikan apabila ternyata dalam kurun waktu satu tahun siswa kelas 7 tidak mengalami kesalahan dalam berbahasa. Karena itu, kebutuhan pembelajarannya berdasarkan kebutuhan konteks kelas.

Kenyataan tersebut sebenarnya dapat menepis anggapan di atas karena dengan begitu, porsi untuk menghadirkan pembelajaran aspek 
Untuk menjawab itu, ada baiknya diperhatikan prinsip-prinsip pembelajaran bahasa secara umum, yakni sebagai berikut: (1) pembelajaran bahasa Indonesia harus diarahkan untuk lebih banyak memberikan porsi kepada perlatihan berbahasa yang nyata; (2) tata bahasa diajarkan hanya untuk membetulkan kesalahan ujaran siswa; (3) keterampilan berbahasa nyata menjadi tujuan utama; (4) membaca sebagai alat untuk belajar (reading for learning); (5) menulis dan berbicara sebagai alat berekspresi dan menyampaikan gagasan; (6) kelas menjadi tempat berlatih menulis, membaca, dan berbicara dalam bahasa; (7) penekanan pengajaran sastra pada membaca sebanyakbanyaknya karya sastra, dan (8) pengajaran kosa kata harus diarahkan untuk menambah kosa kata anak. Berdasarkan hal itu, tampak bahwa arah pembelajaran bahasa adalah memperbanyak berlatih di dalam kelas dengan menggunakan bahasa yang sesuai dengan situasi, baik yang nyata 'senyatanya' melalui diskusi, misalnya, maupun yang nyata 'tidak senyatanya', misalnya melalui kegiatan bermain peran.

Sementara itu, prinsip-prinsip pembelajaran tata bahasa adalah sebagai berikut. Pertama, pembelajaran komponen kebahasaan merupakan pelatihan pemahaman dan penggunaan bahasa yang bermakna sesuai dengan keperluan komunikasi. Dalam hal ini kegiatan utama pembelajaran komponen kebahasaan melalui pemberian latihan yang terus-menerus dalam berbagai situasi kebahasaan yang bermakna. Pelatihan itu harus diarahkan untuk mendukung, baik kemampuan aspek pemahaman (menyimak dan membaca), maupun kemampuan penggunaan (berbicara dan menulis). Kedua, pembelajaran komponen kebahasaan terintegrasi ke dalam pembelajaran keterampilan berbahasa. Prinsip ini sebenarnya merupakan implikasi prinsip pertama. Berdasarkan prinsip ini, komponen kebahasaan tidak diajarkan secara mandiri. Contoh-contoh yang disajikan haruslah yang fungsional berdasarkan penggunaannya, baik secara reseptif, maupun produktif. Dengan demikian, pembelajaran komponen kebahasaan terfokus kepada penggunaan bahasa secara fungsional dan bermakna sesuai dengan tujuan dan keperluan komunikasi. Oleh karena itu pula, pembelajaran kebahasaan mengarah kepada kemungkinan variasi-veriasi berbahasa. Ketiga, pembelajaran komponen kebahasaan tidak menganut tahap-tahap pembelajaran secara linguistis. Komponen fonologi tidak harus diajarkan lebih dahulu dibandingkan dengan komponen morfologi ataupun sintaksis. Pembelajaran sintaksis, misalnya, harus berlangsung secara terpadu berdasarkan wacana yang kontekstual, fungsional, bermakna, dan bermanfaat, baik bagi siswa maupun lingkungannya. Dengan demikian, contoh-contoh kalimat yang konkret berdasarkan wacana itulah yang dapat menjadi bahan kajian. Dalam hal ini, pemilihan bahan yang tepat menjadi kunci keberhasilan pembelajarannya.

Berdasarkan prinsip-prinsip di atas tampak bahwa tata bahasa itu dapat diajarkan (disajikan) kapan saja (di awal, tengah, akhir pelajaran) dan dalam kondisi apa saja (fokus pembelajaran membaca, menulis, berbicara, maupun mendengarkan). Kehadirannya tidak perlu direncanakan karena tata bahasa diajarkan bila terdapat kesalahan pada pemakaian bahasa siswa. Karena itu, urutannya juga akan beragam antara kelas yang satu dengan yang lain pada level yang sama. Secara konkret begini. Materi untuk kelas 8 , misalnya, dapat saja disajikan pada kelas 7 saat itu juga jika memang siswa kelas 7 melakukan kesalahan berbahasa yang sesuai dengan materi 8 dalam lampiran (model Kurikulum 2004). Dengan demikian, guru tidak harus menunda membicarakannya setahun lagi setelah anak duduk di kelas 8. Bagitu pula sebaliknya, kompetensi gramatikal tertentu yang tercantum di kelas 7, misalnya, tidak harus disajikan apabila ternyata dalam kurun waktu satu tahun siswa kelas 7 tidak mengalami kesalahan dalam berbahasa. Karena itu, kebutuhan pembelajarannya berdasarkan kebutuhan konteks kelas.

Kenyataan tersebut sebenarnya dapat menepis anggapan di atas karena dengan begitu, porsi untuk menghadirkan pembelajaran aspek 
tata bahasa menjadi sangat tidak terbatas. Yang menjadi masalah adalah apakah guru-guru bahasa Indonesia siap dengan hal ini? Mereka tentu akan merasa harus menyelesaikan materi hari itu (misalnya berbicara) sehingga apabila ada kesalahan kebahasaan anak dalam berbicara dengan terpaksa (sengaja?) dibiarkan saja. Yang lebih memprihatinkan adalah, barangkali, guru tidak mengetahui bahwa anak melakukan kesalahan. Karena itu, kompetensi guru dalam hal ini dituntut sangat tinggi. Di samping itu, guru harus peka terhadap kesalahan itu.

\section{Sikap Guru terhadap Pengembangan Kurikulum}

Satu hal yang dapat dicatat tentang sikap guru adalah banyak guru yang merasa lebih suka tidak mengembangkan/menyusun silabus sendiri. Mereka lebih suka silabus disusun oleh pemerintah, seperti yang terjadi pada era kurikulum sebelumnya yang berbentuk GBPP. Dengan demikian, guru tidak merasa bersalah jika menyusun silabus berbeda dengan teman sejawatnya. Pada umumnya mereka khawatir terhadap apa yang telah dihasilkannya, yang jangan jangan berbeda dengan orang lain. Kekhawatiran tersebut menyebabkan mereka bersikap apatis.

Sikap berikut mungkin merupakan produk suatu upaya sistematis pada masa lalu, yaitu sikap suka seragam. Sikap ini tidak terlepas dari sikap pertama. Sikap suka seragam selalu merasa tidak nyaman apabila harus menemui hal-hal yang berbeda. Dalam dokumen Kurikulum 2004 ataupun KTSP ditegaskan bahwa dalam mengembangkan silabus setiap pengembang dapat saja berbeda hasilnya dari pengembang yang lain. Bukankah telah dijelaskan bahwa prinsip pelaksanaan kurikulum tersebut adalah kesatuan dalam kebijakan dan keberagaman dalam pelaksanaan. Sikap ini sebenarnya merupakan cerminan sikap kurang percaya diri. Sikap kurang percaya diri ini bisa diakibatkan oleh kompetensi yang kurang. Hal ini akan melahirkan sikap guru yang kurang kreatif. Data empiris yang meyakinkan memang tidak dapat diungkapkan, namun rekaman penulis terhadap fenomena ini cukup menonjol.

Di samping itu, banyak guru yang merasa bahwa beban guru lebih berat sekarang (ketika menggunakan Kurikulum 2004/KTSP) dibandingkan dengan bila mereka menggunakan kurikulum sebelumnya. Beban tersebut berupa beban administrasi untuk menyusun silabus, rencana pelaksanaan pembelajaran, rubrik penilaian, dan sebaginya yang pada waktu pelaksanaan Kurikulum 1994 mereka hanya menyiapkan satuan pembelajaran. Penerlibatan guru dalam kegiatan-kegiatan tersebut dianggap suatu beban yang memberatkan. Padahal, mereka harus pula melaksanakan proses belajar mengajar di kelas. Akibatnya, mereka bersikap masa bodoh dan tidak serius.

Hal itu tentu tidak berlaku bagi semua guru. Guru yang kreatif lebih menyukai tantangan demikian karena mereka dapat menyalurkan ide-ide kreatifnya dalam mengembangkan kurikulum. Namun, kita harus sadar bahwa jumlah guru yang kreatif tidaklah terlalu banyak. Apalagi, kalau kita mau menengok ke sekolah-sekolah di pelosok. Di sana kita dapat menemui guru-guru yang kekurangan fasilitas pendukung untuk mengembangkan kreativitasnya.

\section{Pengembangan Kurikulum yang Dilakukan Guru}

Kendala yang sering terjadi di lapangan dalam pengembangan silabus adalah tidak semua guru dapat mengembangkan silabus dengan baik. Pengetahuan guru yang terbatas tentang materi pembelajaran dan pemahaman kurikulum menjadi pendukung utama kenyataan tersebut.

Yang juga meresahkan guru adalah adanya instruksi dari dinas pendidikan kota/kabupaten untuk ulangan bersama pada setiap semester. Cara ini tidak salah dilakukan ketika guru menggunakan urutan materi yang sama dalam satu semester, seperti yang terjadi di era GBPP dulu. Namun, sekarang kondisinya berbeda. Silabus setiap sekolah bisa berbeda. Hal itu dibenarkan menurut kurikulum. 
Akibatnya, bila instruksi tersebut dilaksanakan saat ini, banyak sekolah yang merasa dirugikan sebab bisa saja siswanya tidak dapat menyelesaikan soal-soal dalam ulangan bersama tersebut sebab kompetensi dasar yang diujikan belum diajarkan. Karena itu, apabila kebijakan tersebut ingin dipertahankan untuk standardisasi sekolah-sekolah di wilayah kerjanya, dinas pendidikan kota/kabupaten (atau mungkin provinsi) harus memfasilitasi penyusunan silabus bersama untuk satu wilayah kerjanya. Dalam pengamatan penulis belum semua kota/kabupaten di tanah air ini melakukan hal ini meskipun mereka melaksanakan ujian bersama setiap tengah semester.

Di samping itu, di lapangan banyak guru yang belum dapat melakukan penilaian autentik dan penilaian proses dengan baik. Dalam hal ini guru harus menyiapkan rubrik untuk penilaian. Pada kenyataannya, penyusunan rubrik ini tidak mudah. Sementara itu, penilaian proses tidak dapat dilakukan pada banyak siswa. Padahal, jumlah murid di sekolah-sekolah kita rata-rata mencapai sekitar empat puluh siswa. Belum lagi muncul pertanyaan apakah penilaian diri siswa sudah dilakukan?

Kesulitan lain yang ditemui guru di lapangan saat ini adalah bagaimana model pelaporan hasil belajar kepada orang tua. Di beberapa sekolah ditemui berbagai model. Bukan itu saja. Para guru merasa sangat berat menuliskan pelaporan hasil belajar model yang dikembangkan KBK/KTSP sebab selama ini mereka telah terbiasa dengan model pelaporan dengan angka-angka yang serba pasti.

Model mengajar yang guru sentris jika disurvai akan lebih banyak kita temukan bila dibandingkan dengan yang murid sentris. Model ini tidak cocok untuk kegiatan belajar mengajar dengan KBK/KTSP. Apalagi, dalam KBK dituntut pembelajaran yang 'enjoyfull learning', pembelajaran yang membuat anak senang/betah melakukannya. Berbagai model pembelajaran yang akhir-akhir ini dikembangkan dan cukup bagus mendukungnya mungkin dapat dihitung dengan jari penerapannya di sekolah-sekolah.

Munculnya berbagai buku pelajaran akhir-akhir ini dengan label sesuai dengan $\mathrm{KBK} / \mathrm{KTSP}$ dan model CTL, di samping menyenangkan bagi guru karena mereka bisa memilih buku yang cocok dengan sekolah mereka, ada pula guru yang menjadi bingung dengan banyaknya pilihan tersebut. Guru yang terbiasa menggunakan buku dengan instruksi akan merasa sulit memilih sendiri buku yang sesuai dengan kebutuhan anak didiknya. Sebaliknya, guru yang tidak sejalan dengan pengharusan menggunakan buku tertentu melalui kebijakan atasan tersebut merasa memperoleh angin segar.

Pemerintah melalui Pusat Perbukuan Departemen Pendidikan Nasional telah melakukan penilaian terhadap buku-buku pelajaran. Pada akhirnya akan dikeluarkan rekomendasi terhadap beberapa buku yang layak dipakai di sekolah. Meskipun demikian, menurut penulis, ada kekurangan dalam proses penilaian yang dilakukan tersebut, baik yang menyangkut beberapa butir instrumen penilaian maupun model penilaiannya (karena kebetulan penulis adalah termasuk tim penilai buku pelajaran).

Dalam KBK/KTSP ditegaskan adanya program remidial. Dalam berbagai kesempatan terdengar bahwa kegiatan ini telah dilaksanakan di beberapa sekolah. Akan tetapi, apakah semua sekolah di wilayah bukan perkotaan telah melaksanakan kegiatan ini dengan baik? Di sekolah-sekolah proyek uji coba KBK tersebut diperoleh data bahwa hanya 59\% guru yang melakukan kegiatan remidial. Pada umumnya mereka menyatakan bahwa tidak ada waktu untuk menyelenggarakannya. Meskpiun demikian, $90 \%$ di antara mereka merasa puas terhadap hasil yang diperoleh (kemajuan) siswa.

Pelaksanaan pengayaan hampir sama dengan remidial; bahkan seakan-akan pengayaan bukan suatu kewajiban sebab batas ketuntasan telah dilampaui oleh siswa. Jumlah yang menyelenggarakan pengayaan kurang dari $50 \%$. Dalam hal ini sebagian kecil siswa yang merasa senang sebab mereka pada umumnya 
malah merasa terbebani dengan tugas-tugas baru.

\section{Kompetensi Guru}

Seperti yang telah dijelaskan di depan bahwa kompetensi guru sangatlah berpengaruh terhadap kinerja guru. Dalam tes kompetensi guru bahasa Indonesia tingkat SMP/MTs secara nasional skor guru yang mencapai nilai 70\% atau lebih rasanya tidak lebih dari 10\%. Karena adanya ketentuan kuota pelatihan yang berupa TOT untuk guru bahasa Indonesia SMP/MTs untuk tingkat nasional, beberapa peserta dengan skor di bawah 50\% terpaksa diikutkan karena memang pertimbangan mewakili daerah. Itu gambaran nyata yang menunjukkan rata-rata kompetensi guru bahasa Indonesia.

Dalam kegiatan TOT tersebut para peserta (yang nota bene adalah guru-guru pilihan karena skor tes kompetensi setelah diranking memenuhi kuota) ditengarai memiliki pemahaman tentang aspek kebahasaan masih rendah. Keluhan serupa dilontarkan pula oleh fasilitator yang menyampaikan materi sastra, metode pembelajaran, dan evaluasi.

Ketika penulis menjadi fasilitator dalam suatu TOT untuk guru bahasa Indonesia MTs se-Madura tahun 2001, penulis sempat tercengang karena di antara 40 peserta dalam satu kelas, hanya ada 3 orang guru yang memiliki latar belakang S1 Pendidikan Bahasa Indonesia. Sarjana di kelas itu kurang dari 50\%. Itu pun sebagian besar bergelar S.Ag. Yang menarik adalah adanya guru bahasa Indonesia MTs yang hanya berpendidikan MTs. Beberapa guru berpendidikan MA (Madrasah Aliya). Itu semua menunjukkan seserpih gambaran kompetensi guru bahasa Indonesia kita.

\section{Dampak Implementasi KBK pada Siswa}

Bagi 41\% siswa SMA uji coba, terhadap penerapan KBK di sekolah mereka merasakan terbebani karena banyaknya tugas untuk mencari informasi tambahan dan tugastugas dari berbagai guru mata pelajaran terasa sangat memberatkan mereka. Dalam hal ini terdapat 59\% siswa yang merasa tidak terbebani. Dari jumlah itu $70 \%$ yang merasa senang karena bisa belajar mandiri, memanfaatkan waktu untuk belajar lebih banyak lagi, menumbuhkan kreativitas, dan dapat menggunakan berbagai referensi.

Pelaksanaan kegiatan remidial, menurut $40 \%$ siswa, juga terasa sangat membebani. Cara yang dilaksanakan guru menurut mereka adalah mengulangi materi yang belum tuntas. Meskipun demikian, sebagian besar (82\%) siswa yang diremidi merasa puas dengan hasil remidi karena telah melampaui batas lulus (tuntas).

\section{Dampak Implementasi KBK/KTSP pada Sarana dan Prasarana Sekolah}

Tugas-tugas pengembangan diri siswa dalam mata pelajaran Bahasa dan Sastra Indonesia banyak diperoleh melalui bahan pustaka. Dalam hal ini peran perpustakaan sekolah menjadi sangat penting dalam pengembangan kurikulum. Jumlah bahan pustaka yang memadai berdasarkan ukuran jumlah siswa dan jenis koleksinya menjadi penentu keberhasilan program belajar mengajar. Ruang baca yang memadai, meskipun tidak sepenting jumlah dan jenis koleksi bahan pustaka, patut diperhitungkan dalam menciptakan iklim belajar yang kondusif.

Dari hasil pengamatan pada tiga sekolah dimaksud, terungkap bahwa ketiga sekolah telah memiliki perpustakaan yang representatif untuk melayani kebutuhan siswanya. Namun, apakah semua sekolah di tanah air ini memiliki fasilitas demikian? Mungkin sekali jika dihitung, tidak lebih dari $25 \%$ sekolah yang memiliki perpustakaan yang baik.

Keterbatasan media pembelajaran untuk pembelajaran bahasa juga dirasakan oleh para guru. Media pembelajaran bahasa yang dijual jumlahnya tidak banyak. Media buatan guru, di samping membuatnya memerlukan waktu yang tidak sedikit, kadang-kadang bahannya sulit diperoleh (ini banyak dirasakan 
guru-guru luar Jawa di daerah terpencil).

Yang termasuk dalam sarana yang juga penting adalah papan pajang. Ternyata tidak semua ruang kelas dalam suatu sekolah memiliki papan pajang. Papan pajang yang ideal pada setiap ruang kelas harus tersedia. Ukurannya harus cukup besar sehingga dapat menampung seluruh hasil kerja siswa. Rasanya guru kurang adil jika hanya memajang hasil pekerjaan siswa secara sampling. Siswa yang karyanya tidak pernah dipajang akan merasa minder, kurang percaya diri. Sikap ini kurang menguntungkan sebab anak yang bersangkutan akan mengambil sikap apatis, acuh tak acuh. Meskipun sebenarnya fasilitas ini tidak terlalu mahal secara ekonomis, manfaatnya sangat besar bagi siswa.

\section{PENUTUP}

Uraian di depan mengungkapkan betapa masih banyaknya problematika pengimplementasian KBK/KTSP di sekolah, terutama sekali di sekolah-sekolah pelosok. Upaya yang terus-menerus untuk meningkatkan kualitas guru bahasa Indonesia sehingga mereka memiliki kompetensi yang memadai (profesional) menjadi impian yang harus diwujudkan karena dari guru-guru yang profesional inilah harapan bangsa diserahkan. Penyediaan sarana yang memadai akan menjadi pendukung yang kokoh. Semoga.

\section{DAFTAR PUSTAKA}

Dit. PLP. 2003. Kurikulum Bahasa Indonesia. Bahan Pelatihan Terintegrasi Berbasis Kompetensi. Jakarta.
Dorros, Sidney. 1978. Teaching as Profession. Columbus: Charles E. Merrill Publishing Company.

Goodlad, John I. 1984. A Place Called Scholl. New York: McGraw-Hill Book Company.

Kompas. 2001. "Mendiknas Ingin Rekrutmen Guru Tetap oleh Pemerintah Pusat". 18 Januari. Jakarta.

Kuswandi. 2005". Implementasi Kurikulum Berbasis Kompetensi di SMA Kota Surabaya (Suatu kajian tentang Implementasi KBK di 3 SMA Surabaya)". Draf Disertasi Tidak Diterbitkan. Surabaya: Untag.

Moedjiharto. 2000. "Profesionalisme Guru untuk Merespon Otonomi Daerah". Dalam Media Informasi dan Komunikasi Unesa. Oktober.

Nunan, David. 1988. The Learner-Centred Curriculum. New York: Cambridge University Press.

Richards, Jack C. 2001. Curriculum Development in Language Teaching. New York: Cambridge University Press.

Stinnett, T.M. 1968. Proffesional Problems of Teachers. NewYork: The Macmillan Company.

Suryadi, Ace. 2001. "Menyoal Mutu Profesi Guru". Dalam Kompas. 9 Maret. Jakarta.

Suyanto. 2001. "Guru yang Profesional dan Efektif". Dalam Kompas. 16 Februari. Jakarta. 